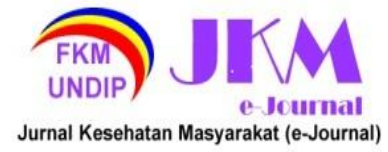

\title{
IMPLEMENTASI PROGRAM JOGO TONGO DALAM MENANGGULANGI COVID-19 : STUDI KASUS DI KELURAHAN SISWODIPURAN KABUPATEN BOYOLALI
}

\author{
Ervina Yuni Ariani ${ }^{1 *}$, Rani Tyas Budiyanti ${ }^{2}$, Wulan Kusumastuti ${ }^{2}$ \\ ${ }_{1}^{1}$ Peminatan Administrasi dan Kebijakan Kesehatan Fakultas Kesehatan Masyarakat Universitas \\ Diponegoro Jl. Prof. H. Soedarto, S.H.,Tembalang, Semarang, Indonesia \\ ${ }^{2}$ Bagian Administrasi dan Kebijakan Kesehatan Fakultas Kesehatan Masyarakat Universitas Diponegoro \\ Jl. Prof. H. Soedarto, S.H.,Tembalang, Semarang, Indonesia \\ ${ }^{*}$ Corresponding author: ervinaariani00@gmail.com
}

Penemuan kasus COVID-19 di Indonesia terus mengalami penambahan jumlah sehingga segera diperlukan upaya penanggulangan. Menyikapi hal itu, Pemprov Jateng mengeluarkan Instruksi Gubernur No.1 Tahun 2020 tentang Pemberdayaan Masyarakat dalam Percepatan Penanganan COVID-19 di Tingkat RW melalui pembentukan Satgas Jogo Tonggo. Kelurahan Siswodipuran merupakan salah satu wilayah di Kabupaten Boyolali, Jawa Tengah dengan peningkatan kasus COVID-19 setiap bulannya dan ditemukan total 36 warga terkonfirmasi. Dukuh Gatak RW 05 meruapakan daerah perkotaan padat penduduk yang rawan akan penyebaran COVID-19. Seluruh wilayah RT di Dukuh Gatak pernah ditemukan kasus konfirmasi serta terdapat cluster baru penyebaran virus di wilayah tersebut, akan tetapi masih tedapat warga yang kurang peduli dan belum mengetahui akan pelaksanaan program Jogo Tonggo. Artikel ini menggunakan metode kualitatif dengan pendekatan deskriptif. Hasil penelitian menunjukkan bahwa program Jogo Tonggo Dukuh Gatak, Siswodipuran belum optimal, hanya sedikit kegiatan bidang Jogo Tonggo yang berhasil di implementasikan. Pelaksanaan program belum optimal disebabkan oleh beberapa faktor, yaitu pelaksana yang kurang memahami tujuan dari program sehingga menyebabkan presepsi yang berbeda mengenai mekanisme pelaksanaannya. Pelaporan Jogo Tonggo tidak berjalan secara rutin dan tertulis dan tidak terdapat pelatihan anggota Satgas maupun anggaran khusus. Fasilitas dan sarana prasarana yang tersedia masih terbatas serta belum semua anggota Satgas berperan aktif karena ketergantungan yang tinggi pada Ketua RW dan pemerintah desa. SOP Jogo Tonggo tingkat RT/RW belum terbentuk, begitu juga dengan sosialisasi kepada anggota Satgas maupun masyarakat yang masih sangat minim.

Kata kunci: COVID-19, Jogo Tonggo, Pemberdayaan Masyarakat, Satgas

\section{PENDAHULUAN}

COVID-19 merupakan penyakit menular yang disebabkan oleh SARS-CoV-2 jenis baru yang belum diidentifikasi sebelumnya pada manusia dan diketahui menyebabkan penyakit dengan menimbulkan gejala berat seperti MERS dan SARS. ${ }^{1}$ Penyebaran kasus sangat cepat di Indonesia dimana update data per 2 Desember 2020 menembus angka 549.508 dengan 17.355 kematian. ${ }^{2}$ Pada Provinsi Jawa Tengah sendiri mencapai 58.321 kasus dengan 3.929 kematian. ${ }^{3}$ Sedangkan Kabupaten Boyolali yang termasuk kedalam 10 besar kabupaten dengan kasus COVID-19 tinggi di Jateng di temukan sebanyak 2.131 kasus dengan 411 pasien isolasi mandiri dan 72 meninggal dunia. ${ }^{4}$

Provinsi Jawa Tengah dengan kasus penemuan COVID-19 tinggi mengeluarkan program berbasis pemberdayaan masyarakat melalui program Jogo Tonggo. Program Jogo
Tonggo merupakan gerakan percepatan penanganan pandemi COVID-19 dengan basis pemberdayaan masyarakat yang ditetpakan oleh Gubernur Jateng melalui Instruksi Gubernur No.1 Tahun 2020. Dalam praktiknya melibatkan masyarakat sebagai garda terdepan bersama dengan pemerintah saling mendukung terkait penanggulangan COVID-19 yang dilaksanakan pada tingkat RW. ${ }^{5}$ Program Jogo Tonggo sendiri dijadikan sebagai program unggulan yang menjadi fokus Pemkab Boyolali dalam memberdayakan masyarakat untuk pengendalian kasus COVID-19.

Kabupaten Boyolali termasuk kedalam zona merah dimana kasus COVID-19 terus mengalami kenaikan dan tersebar di hampir seluruh kecamatan. Kecamatan Boyolali merupakan kecamatan dengan penemuan kasus tertinggi terutama di Kelurahan Siswodipuran. Peningkatan kasus COVID-19 di 


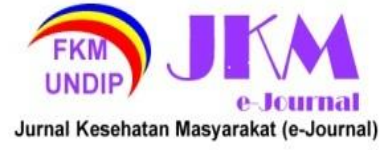

Kelurahan Siswodipuran terjadi setiap bulannya. Update data per 2 Desember 2020 ditemukan total 36 warga konfirmasi COVID-19 diwilayah tersebut.

Pelaksanaan Jogo Tonggo Kelurahan Siswodipuran telah dijalankan di $17 \mathrm{RW}$, dimana RW 05 Dk.Gatak merupakan dukuh dengan pelaksanaan Jogo Tonggo paling aktif dan telah mencakup 4 bidang yaitu bidang kesehatan, ekonomi, sosial dan keamanan, serta hiburan. Dk.Gatak sendiri merupakan wilayah perkotaan padat penduduk yang dekat dengan pusat pemerintahan Kabupaten Boyolali serta dikelilingi oleh jalan protokol yang memiliki tingkat mobilisasi tinggi. Sebagian besar dari warga Dk.Gatak berprofesi sebagai pedagang dan pengusaha tempat makan sehingga mengharuskan mereka untuk melakukan kontak dengan banyak orang.

Dukuh Gatak RW 05 terdiri dari 5 RT, dimana dari seluruh RT pernah ditemukan warga dengan kasus konfirmasi positif. Selain itu, Dk.Gatak juga pernah terdapat cluster baru penyebaran COVID-19 yaitu cluster piknik keluarga, dimana hal ini menyebabkan ledakan kasus COVID-19 di wilayah tersebut pada akhir tahun 2020. Akan tetapi masih dapat ditemukan warga Dukuh Gatak yang kurang peduli dengan penanggulangan COVID-19 dan belum mengetahui akan pelaksanaan program Jogo Tonggo. Terdapat warga Dk.Gatak mengaku bahwa belum mendapat edukasi dan informasi mengenai Jogo Tonggo. Sehingga tujuan dari penelitian ini adalah untuk mendeskripsikan pelaksanaan dan faktor yang mempengaruhi implementasi program Jogo Tonggo di Kelurahan Siswodipuran Kabupaten Boyolali.

\section{METODE PENELITIAN}

kualitatif dengan pendekatan deskripstif observasional yang dilakukan pada bulan MaretApril 2021 di Dk.Gatak RW 05, Siswodipuran, Boyolali. Penelitian melalui wawancara mendalam pada subjek penelitian yang di tentukan berdasarkan teknik non probabilitas purposive sampling, dimana informan utama adalah ketua dan perwakilan 4 bidang Satgas Jogo Tonggo Dk.Gatak, sedangkan informan triangulasi meliputi ketua dan perwakilan bidang kesehatan serta bidang KIE Satgas COVID-19 Kelurahan Siswodipuran, perwakilan dari Ketua RT, dan perwakilan dari masyarakat Dk.Gatak. Analisis menggunakan teori implementasi Van
Meter Van Horn (1995) pada variabel ukuran dan tujuan program, sumber daya manusia dan keuangan, komunikasi, karakteristik agen pelaksana, lingkungan sosial dan politik, serta disposisi pelaksana. Penelitian ini telah lolos kaji etik dengan No: 40/EA/KEPK-FKM/2021.

\section{HASIL DAN PEMBAHASAN}

\section{Karakteristik Informan Penelitian}

Tabel 1. Karakteristik Informan Utama Pelaksanaan Program Jogo Tonggo

\begin{tabular}{|c|c|c|c|c|}
\hline Inisial & $\frac{\text { Usia }}{\text { (Tahun) }}$ & $\frac{\text { Jenis }}{\text { Kelamin }}$ & $\frac{\text { Pendidikan }}{\text { Terakhir }}$ & Jabatan \\
\hline UU1 & 53 & $\mathrm{~L}$ & S1 Teknik Sipil & $\begin{array}{l}\text { Sekretaris Satgas } \\
\text { Jogo Tonggo } \\
\text { Dukuh Gatak }\end{array}$ \\
\hline IU 2 & 45 & $P$ & SLTA & $\begin{array}{l}\text { Perwakilan Bidang } \\
\text { Kesehatan }\end{array}$ \\
\hline IU3 & 45 & L & SLTA & $\begin{array}{l}\text { Perwakilan Bidang } \\
\text { Ekonomi }\end{array}$ \\
\hline IU 4 & 47 & L & D1 Akutansi & $\begin{array}{l}\text { Perwakilan Bidang } \\
\text { Sosial Keamanan }\end{array}$ \\
\hline IU 5 & 52 & L & S1 Penjasorkes & $\begin{array}{l}\text { Perwakilan Bidang } \\
\text { Hiburan }\end{array}$ \\
\hline
\end{tabular}

Tabel 2. Karakteristik Informan Triangulasi Pelaksanaan Program Jogo Tonggo

\begin{tabular}{|c|c|c|c|c|}
\hline Inisial & Usia & $\frac{\text { Jenis }}{\text { Kelamin }}$ & $\frac{\text { Pendidikan }}{\text { Terakhir }}$ & Jabatan \\
\hline IT1 & 40 & L & S1 Pertanian & $\begin{array}{l}\text { Ketua } \| \text { Satgas } \\
\text { COVID-19 }\end{array}$ \\
\hline IT2 & 45 & L & S1 Sosial Politik & $\begin{array}{l}\text { Perwakilan Sie } \\
\text { Komunikasi, } \\
\text { Informasi \& Edukasi }\end{array}$ \\
\hline IT3 & 45 & P & D3 Kebidanan & $\begin{array}{l}\text { Perwakilan Sie } \\
\text { Kesehatan }\end{array}$ \\
\hline IT 4 & 68 & L & SLTP & $\overline{\text { Ketua RT }}$ \\
\hline IT5 & 40 & L & SLTA & Masyarakat \\
\hline
\end{tabular}

Sedangkan pada tabel 2 diketahui bahwa informan triangulasi terdiri dari 4 informan laki-laki dan 1 informan perempuan dengan rentang usia antara 40-68 tahun dan pendidikan terakhir SLTP-S1.

\footnotetext{
Pelaksanaan Program Jogo Tonggo di Dukuh Gatak Kelurahan Siswodipuran Boyolali
} 


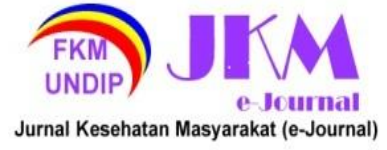

Program Jogo Tonggo di Kelurahan Siswodipuran telah sampai pada tingkat RT/RW, dimana Dukuh Gatak RW 05 merupakan yang paling aktif dan telah mencakup 4 bidang Jogo Tonggo. Struktur organisasi Satgas Jogo Tonggo Dk.Gatak telah terbentuk 5 hari setelah Instruksi Gubernur dikeluarkan yaitu pada tanggal 30 April 2020. Namun, kasus COVID-19 pernah di temukan di seluruh RT di Dk.Gatak. Cluster baru penularan COVID-19 juga ditemukan di dukuh ini yaitu cluster piknik keluarga pada akhir tahun 2020.

Pelaksanaan program Jogo Tonggo di Dk.Gatak, Siswodipuran belum berjalan optimal dengan hanya sebagain kecil kegiatan bidang Jogo Tonggo yang berhasil di implementasikan. Pada bidang kesehatan baru terlaksana 4 dari 8 kegiatan, yaitu menyarankan warga yang terjaring tracing COVID-19 untuk melakukan isolasi mandiri, melakukan penyemprotan desinfektan dan pembagian masker kepada warga, memberikan pelayanan kesehatan dasar pencegahan COVID-19 dengan menggunakan sarana komunikasi, serta berkoordinasi dengan Puskesmas dan Dinas Kesehatan dalam pemeriksaan COVID-19 lebih lanjut. Sedangkan untuk kegiatan yang belum terlaksana meliputi meregistrasi setiap orang yang keluar masuk RW, registrasi diikuti dengan tindakan pencegahan COVID-19, update data harian status kesehatan warga (suspect, probable, konfirmasi, discard), serta mendorong praktek hidup bersih dan sehat.

Temuan pada penelitian ini bahwa pelaksanaan isolasi dilakukan di rumah masingmasing, dimana rumah yang dijadikan sebagai tempat isolasi mandiri telah memenuhi syarat protokol karantina yaitu ventilasi baik, menyediakan ruangan khusus, dan melaksanakan protokol kesehatan ketat. ${ }^{6}$ Selain itu, pada kegiatan penyemprotan desinfektan masih terdapat warga yang tidak mengenakan APD dengan baik. Penyemprotan desinfektan dapat mencegah penyebaran COVID-19 secara efektif apabila mengguankan bahan dan juga metode yang tepat. ${ }^{7}$ Namun desinfektan merupakan cairan bahan kimia yang dapat berbahaya jika terkena kulit atau sistem pernapasan bahkan dapat mengakibatkan kematian. Sehingga penting bagi para petugas untuk menggunakan APD yang lengkap. ${ }^{8}$

Pemberian himbauan kepada masyarakat lebih banyak dilakukan secara online dan hanya fokus pada himbauan COVID-
19 seperti protokol kesehatan dan 5M, sedangkan kegiatan PHBS belum menjadi fokus pada pelaksanaan Jogo Tonggo Dk.Gatak. Seharusnya tenaga kesehatan yang menjadi anggota Satgas Jogo Tonggo dapat memberikan edukasi PHBS dengan pengetahuan dan pemahaman yang dimiliki. Pencegahan pandemi COVID-19 tidak selesai hanya dengan penerapan social distancing, akan tetapi harus di barengi dengan penerapan PHBS seperti rajin mencuci tangan dengan baik dan benar, menerapkan etika batuk, serta menjaga kesehatan dan sistem kekebalan tubuh. ${ }^{9}$ Koordinasi dengan Puskesmas dan Dinkes telah dilakukan dalam upaya penanganan kasus COVID-19 lebih lanjut terkait tracing, testing dan treatment.

Pelaksanaan registrasi dan update kesehatan warga dapat dikoordinir oleh masingmasing RT melalui via WhatsAap, dengan muatan data warga yang keluar masuk Dk.Gatak, data warga yang melakukan isolasi mandiri, warga dengan status rentan COVID-19 dan pemantauan warga yang memiliki status kesehatan kurang baik.

Pada bidang ekonomi hanya dapat melaksanakan 3 dari 9 kegiatan Jogo Tonggo yaitu pengupayaan pemenuhan kebutuhan warga kurang pangan, memastikan kegiatan produksi warung/toko tetap berjalan, dan memberikan bantuan kebutuhan belanja makan bagi warga yang melakukan isolasi mandiri. Sedangkan kegiatan yang belum terlaksana yaitu pendataan kebutuhan dasar dan ketersediaan pangan warga RW, pendataan warga yang tidak berdaya dalam menyediakan kebutuhan dasar, memastikan bantuan tunai dan non tunai tepat sasaran, mendorong terjadinya pertukaran barang, makanan dan jasa antar warga RW, terbangunnya lumbung pangan, serta mengembangkan gerakan menanam tanaman pangan.

Pemenuhan kebutuhan pangan warga kurang mampu dilakukan dengan membuat papan yang diberi gantungan untuk menggantungkan bahan makan gratis yang akan diisi oleh warga Dk.Gatak secara sukarela. COVID-19 selain membatasi ruang gerak juga mempengharuhi kondisi ekonomi yang berdampak pada kemampuan masyarakat untuk mendapatkan pangan. ${ }^{10}$ Kegiatan ini seharusnya dapat lebih efektif jika didukung dengan pendataan kebutuhan dan jumlah warga 


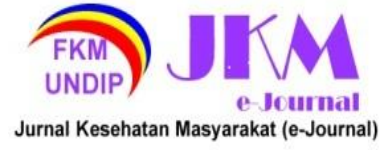

yang kurang mampu dalam hal pemenuhan pangan selama pandemi.

Produksi warung/toko di Dk.Gatak tetap berjalan dengan protokol kesehatan, namun pelaksanaan protokol kesehatan oleh warga masih rendah, penggunaan alat cuci tangan dan masker dinilai masih kurang. Satgas Jogo Tonggo menghimbau warga agar memprioritaskan berbelanja pada warung dalam lingkup $1 \mathrm{RW}$ untuk meminimalkan penularan COVID-19 dan menggerakan roda perekonomian. Selain itu, Satgas Jogo Tonggo besama-sama dengan warga Dk.Gatak memberikan bantuan penjaminan kebutuhan pangan warga yang melakukan isolasi mandri yang dikoordinir oleh ibu-ibu PKK, serta penyaluran bantuan sembako dari Dinas Sosial Kabupaten Boyolali melalui Satgas COVID-19 Kelurahan dan Satgas Jogo Tonggo.

Lumbung pangan seharusnya berfungsi sebagai sumber pangan yang dihasilkan sendiri oleh suatu wilayah secara gotong royong ${ }^{11}$, namun di Dk.Gatak belum terbentuk diakibatkan mayoritas warga berprofesi sebagai pengusaha dan pedagang. Tidak ditemukan warga yang berprofesi sebagai petani dimana kawasan Dk.Gatak merupakan wilayah perkotaan padat penduduk dengan penggunaan lahan mayoritas sebagai sektor usaha dan perumahan, hampir tidak ditemukan area persawahan maupun perkebunan dan saluran irigasi. ${ }^{12} \mathrm{Hal}$ ini juga menyebabkan kegiatan gerakan menanam tanaman pangan, sayur, buah, bumbu dan apotik hidup di lingkungan rumah serta lahan milik umum tidak terlaksana di Dk.Gatak.

Bidang sosial dan keamanan Satgas Jogo Tonggo Dk.Gatak baru berhasil melaksanakan 5 dari 12 kegiatan yaitu meningkatkan keamanan lingkungan, memantau warga isolasi mandiri, mengusulkan bantuan, meningkatkan gotong royong, dan meredam konflik. Sedangkan kegiatan yang belum terlaksana meliputi pencatatan warga keluar masuk lingkungan RW, menghindarkan kerumunan, perlindungan kelompok rentan, memastikan terdapat kentongan di setiap rumah, penerapan jam berkunjung, memastikan kondusifitas, dan pengamanan warung 9 bahan pokok.

Peningkatan keamanan lingkungan Dk.Gatak dilakukan dengan membangun portal masuk dan kegiatan ronda malam, namun belum terdapat jam malam berkunjung warga. Penerapan pos jaga gerbang dalam membatasi jalan masuk ke suatu wilayah dapat dilakukan dengan pembangunan portal dan jaga malam. ${ }^{11}$ Alat komunikasi kentongan sudah lama ditinggalkan warga Dukuh Gatak, komunikasi lebih banyak dilakukan melalui media WhatsApp.

Penjaminan perlindungan kepada kelompok rentan belum terlaksana di Dukuh Gatak. Padahal kelompok rentan memiliki risiko lebih tinggi terpapar COVID-19 dan dapat membawanya kepada kematian, kelompok rentan meliputi lansia, penderita penyakit kronis, perokok, kaum pria dan golongan darah $\mathrm{A} .{ }^{13}$

Penyelesaian konflik dengan musyawarah dan gotong royong dapat dilihat dari kasus mediasi kepada kelompok pendatang yang melanggar prokes dan dapat ditangani oleh bidang sosial dan keamanan bersamasama dengan warga Dk.Gatak melalui musyawarah.

Sedangkan pada bidang hiburan, Satgas Jogo Tonggo Dk.Gatak telah melakukan pembuatan video cover lagu yang melibatkan talent anggota Satgas Jogo Tonggo di masingmasing RT. Selain itu, Satgas pernah memberikan video kuis teka-teki lucu, yang di bagikan melalui grub WhatsApp tiap RT. Hal ini dilakukan dengan tujuan untuk mengurangi kejenuhan dan memberikan hiburan bagi warga. Pelaksanaan hiburan tidak harus dengan pengadaan acara besar, dapat dilakukan dengan pementasan kesenian lokal, lomba online, penyelenggaraan musik virtual, dan lainnya. ${ }^{14}$

\section{Ukuran dan Tujuan Program Jogo Tonggo}

Sasaran pada program Jogo Tonggo ini adalah seluruh warga Dk.Gatak, terutama warga yang terdampak dan terpapar COVID-19. Hasil penelitan mennjukkan bahwa Satgas Jogo Tonggo Dk.Gatak memiliki pendapat yang berbeda-beda mengenai tujuan serta indikator keberhasilan dari program. Adanya perbedaan interpretasi dari tujuan kebijakan akan menimbulkan kegagalan dalam pelaksanaan program. ${ }^{15}$

Selain itu, pelaporan program belum dilaksanakan secara rutin dan tertulis, pelaporan hanya dilakukan secara kondisional jika ditemukan kasus baru dan perkembangan kasus COVID-19. Rentang kendali Satgas Jogo Tonggo seharusnya memberikan laporan secara rutin setiap hari kepada kelurahan yang berisikan data warga yang dirawat dan sembuh dari RS, penyaluran bantuan, pemantauan 


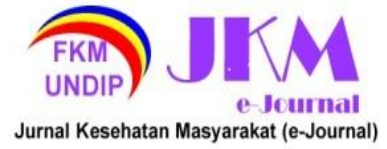

karantina mandiri, ketersediaan 9 bahan pokok, jam kunjungan warga, jadwal ronda dan informasi penting lainnya. ${ }^{14}$

Dari hasil analisis, pelaksana Jogo Tonggo belum semuanya memiliki pengetahuan yang baik mengenai ukuran dan tujuan program sehingga terjadi pemahaman dan persepsi yang berbeda. Kurangnya pengetahuan pelaksana dapat disebabkan oleh kurangnya sosialisasi dari pihak terkait. ${ }^{16}$

2. Sumber Daya Manusia dan Keuangan Program Jogo Tonggo

Sumber daya manusia yang terlibat dalam Jogo Tonggo di Dk.Gatak meliputi seluruh unsur masyarakat yaitu anggota Satgas, kelompok RT, ibu PKK, pengurus RW, karang taruna dan masyarakat umum. Dalam struktur organisasi Satgas Jogo Tonggo Dk.Gatak melibatkan unsur kelembagaan RT dan RW beserta tokoh masyarakat dengan jumlah 22 orang serta telah melibatkan tenaga kesehatan sesuai dengan Juknis Jogo Tonggo. Latar belakang pendidikan informan yaitu SLTA, D1 dan $\mathrm{S} 1$ yang menunjukkan tingkat kompetensi seharusnya sudah mencukupi, namun hal ini tidak didukung dengan adanya pelatihan untuk meningkatkan kapasitas sumberdaya manusia. Seharusnya dalam peningkatan kapasitas SDM dapat dilakukan dengan sosialisasi, table top exercises/drilling dan simulasi. Pelaksana yang tidak kompeten akan berisiko menyebabkan kegagalan pelaksanaan program..$^{6,16}$

Pelaksanaan program Jogo Tonggo Dk.Gatak hanya bertumpu kepada dana swadaya masyarakat melalui kas masingmasing RT dan mengandalkan pada donatur. Tidak terdapat anggaran dana khusus dari pihak RW maupun bantuan operasional dari pihak Kelurahan Siswodipuran. Keberhasilan implementasi program Jogo Tonggo secara efektif perlu ditunjang oleh angaran dalam operasionalnya. ${ }^{16}$ Fasilitas sarana dan prasarana yang digunakan yaitu posko Jogo Tonggo yang berada di balai RW dan bantuan operasional kit Jogo Tonggo dari pemerintah yang jumlahnya terbatas. Tidak terdapat fasilitas khusus karantina mandiri dan lumbung pangan. Padahal pada Juknis Jogo Tonggo telah di sebutkan bahwa sarana prasarana dalam pelaksanaan program Jogo Tonggo meliputi posko Jogo Tonggo di masing-masing balai RW, ruang isolasi/karantina, alat komunikasi, alat-alat kesehatan, bahan KIE, dan buku pedoman Jogo Tonggo. ${ }^{6}$

\section{Komunikasi Program Jogo Tonggo}

Sosialisasi terkait program Jogo Tonggo oleh pemerintah desa kepada anggota Satgas masih sangat minim, seluruh informasi dan koordinasi dilakukan hanya melalui media WhatsApp melalui ketua RW selaku ketua Satgas. Kurangnya sosialisasi mengakibatkan keterbatasan pengetahuan pelaksana dalam menjalankan tugas dan wewenangnya, ukuran dan tujuan program perlu di komunikasikan dengan baik oleh pelaksana. ${ }^{17,15}$

Informasi yang diberikan Satgas Jogo Tonggo kepada warga Dk.Gatak tidak dilakukan secara rutin, edukasi dilakukan bersamaan dengan pendampingan Satgas dalam program Jogo Tonggo dan melalui online dengan media grub WhatsApp. Edukasi dilakukan secara rutin dan aktif dengan masyarakat melalui komunikasi risiko bertujuan untuk membangun kepercayaan publik terhadap program. ${ }^{18}$ Pemberian edukasi yang kurang massif kepada masyarakat mengakibatkan perbedaan tingkat pemahaman warga Dk.Gatak terkait program penanggulangan COVID-19. Pengetahuan yang baik akan mempengaruhi perilaku masyarakat dalam upaya penanggulangan COVID-19 secara tepat, kesadaran akan tumbuh jika pengetahuan baik. ${ }^{19}$

Informasi yang diberikan kepada Satgas maupun masyarakat Dk.Gatak konsisten dan tidak berubah-ubah. Perubahan informasi hanya sebatas pada update regulasi dari pemerintah. Komunikasi yang dilakukan harus konsisten dan jelas, jika perintah berubah-ubah akan menyebabkan timbulnya kebingungan bagi penerima informasi. ${ }^{17}$

4. Karakteristik Agen Pelaksana Program Jogo Tonggo

Dalam struktur organisasi Satgas Jogo Tonggo Dk.Gatak terdiri dari tokoh-tokoh masyarakat yang ditunjuk oleh ketua RW berdasarkan kemauan dan kemampuan dalam menjalan tugas. Tokoh masyrakat di ambil dari perwakilan masing-masing RT dan dibagi kedalam 4 bidang Jogo Tonggo berdasarkan keahlian masing-masing. Pembentukan struktur organisasi yang disesuaikan dengan passion akan memperlancar mekanisme koordinasi. ${ }^{17}$ Akan tetapi dalam implementasi kegiatan Jogo Tonggo dilaksanakan secara bersama-sama dan tidak sesuai dengan bidangnya masingmasing. Hal ini akan berakibat pada kurang aktifnya anggota lain dalam pelaksanaan 


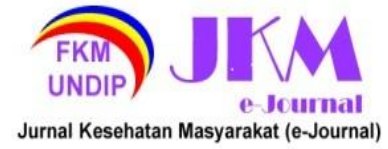

kegiatan program, terutama pada kelompok pemuda. ${ }^{16}$

Dk.Gatak belum terdapat SOP Jogo Tonggo tingkat RT/RW sebagai pedoman pelaksanaan program, selama ini hanya mengacu kepada Instruksi Gubernur No. 1 tahun 2020 serta bergantung pada arahanarahan atau perintah dari ketua RW dan pemerintah desa/kelurahan. SOP diperlukan sebagai acuan dalam bekerjanya pelaksana program (implementor) dimana harus mencantumkan kerangka kerja yang jelas, mudah dipahami dan sistematis. ${ }^{17}$

5. Lingkungan Sosial dan Politik Program Jogo Tonggo

Pemerintah memberikan dukungan dalam pelaksanaan program Jogo Tonggo dalam bentuk payung hukum atau pemberian regulasi, penyaluran bantuan baik sembako maupun uang, bantuan penyemprotan desinfeksi, pelaksanaan tracing, testing dan treatment, serta bantuan operasional kit Jogo Tonggo. Terkait dengan pendisiplinan warga dibantu oleh pihak Kepolisian serta TNI melalui Babinsa dan Babinkamtibmas bersama Satpol PP. Akan tetapi, Puskesmas Boyolali 1 dalam hal ini kurang memberikan edukasi dan sosialisasi kepada Satgas maupun masyarakat dalam hal kesehatan. Kegiatan pemberian himbauan seperti ambulance keliling sangat perlu untuk diaktifkan kembali. Selain itu, pihak Puskesmas seharusnya dapat memberikan bantuan terkait analisis data kesehatan masyarakat dan memberikan saran upaya kesehatan kepada RT/RW.

Dukungan tokoh masyarakat dalam hal ini dapat dilihat dalam keterlibatannya selama pelaksanaan program Jogo Tonggo, membantu memberikan arahan dan edukasi kepada warga Dk.Gatak, pemberian bantuan berupa sembako, uang, desinfeksi, masker kepada warga secara sukarela. Tokoh masyarakat disini memiliki peran penting yang memberikan pengaruh besar pada perilaku warga. ${ }^{6}$

Warga merasa terbantu dengan adanya program Jogo Tonggo, mereka memiliki pedoman dalam upaya penanggulangan COVID-19 di lingkungannya serta mempermudah dalam melakukan koordinasi dengan pemerintah desa/kelurahan. Dukungan warga dapat dilihat dari keikutsertaan selama pelaksanaan program, pemberian bantuan kepada tetangga yang isolasi mandiri secara skarela, memberikan dukungan moril, melaporkan kasus kepada Satgas. Selama pelaksanaan program Jogo Tonggo tidak pernah mendapat laporan penolakan warga terhadap program tersebut maupun permasalahan dengan para pelaksana. Akan tetapi masih dapat ditemukan warga yang acuh dengan upaya penanggulangan COVID-19, mereka tidak mempercayai akan adanya virus. Hal ini tentunya dapat menghambat dalam pelaksanaan program, kasus seperti ini mayoritas dutemukan pada warga dengan pendidikan, ekonomi dan sosial rendah. Karena seseorang dengan pendidikan yang tinggi memiliki pegetahuan yang lebih luas serta lebih mudah dalam menerima pengetahuan baru. ${ }^{17}$

6. Disposisi Pelaksana Program Jogo Tonggo Satgas Jogo Tonggo Dk.Gatak memiliki pemahaman yang berbeda-beda mengenai pelaksanaan program, perbedaan ini mengakibatkan ketidak jelasan ukuran dan tujuan dari program Jogo Tonggo sehingga mempengaruhi pola kerja Satgas. Satgas Jogo Tonggo menilai bahwa pelaksanaan program sudah berjalan dengan baik, namun kenyataan di lapangan menunjukkan bahwa masih banyak kegiatan Jogo Tonggo yang belum berhasil di laksanakan. Program ini merupakan hal baru bagi warga Dk.Gatak, sehingga memang masih memerlukan pendampingan dari pihak-pihak terkait seperti Satgas Kelurahan, Puskesmas dan Dinas Kesehatan.

Satgas Jogo Tonggo menyadari bahwa program ini merupakan kegiatan sosial yang di instruksikan pada level RT/RW sehingga memang harus dipatuhi dan merupakan tanggungjawab yang harus diselesaikan dengan baik. Tidak terdapat bayaran/gaji bukan berarti tidak maksimal dalam pelaksanaan tugas sebagai bentuk pengabdian kepada masyarakat Dk.Gatak. Motivasi datang dari dalam diri untuk dapat melakukan tugas, sehingga mau bekerja dengan ikhlas demi tercapai tujuan organisasi yang efektif dan efisien. ${ }^{17}$

Bedasarkan hasil penelitan, dapat dilihat bahwa anggota Satgas telah menunjukkan sikap dan respon yang baik kepada antar anggota Satgas, masyarakat maupun stakeholder. Walaupun masih terdapat anggota yang kurang aktif selama pelaksanaan program, namun komitmen dan tingkat kepercayaan terhadap keberhasilan program sudah cukup baik. Hasil analisis memperlihatkan bahwa sikap, respon, komitmen dan kepercayaan yang baik akan tetapi tidak didukung dengan adanya sosialisasi 


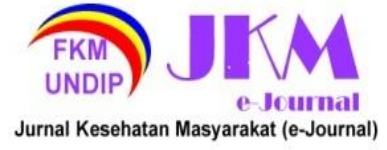

yang maksimal serta pelatihan SDM mengakibatkan kurangnya pengetahuan dan perbedaan presepsi atau interpretasi pelaksana, hal ini dapat menghambat pelaksanaan program Jogo Tonggo di Dk.Gatak.

Prinsip Pemberdayaan Masyarakat pada Impelementasi Program Jogo di Kelurahan Siswodipuran Kabupaten Boyolali Tonggo

Pemberdayaan masyarakat dalam hal ini melibatkan warga Dk.Gatak RW 05 dalam peningkatan kesiagaan dan kesiapan penanggulangan COVID-19. Sesuai dengan Instruksi Gubernur No.1 tahun 2020 bahwa pelaksanaan Jogo Tonggo dilakukan dengan prinsip gotong royong bersama dengan masyarakat sebagai garda terdepan penanggulangan COVID-19. ${ }^{14}$

Program Jogo Tonggo seharusnya melibatkan semua pihak dari unsur masyarakat maupun pemerintah seperti TNI dan Polri, perusahaan milik negara, daerah dan swasta, perguruan tinggi, lembaga professional, lembaga swadaya masyarakat, dan pemangku kepentingan lainnya. ${ }^{20}$ Namun pelaksanaan di Dk.Gatak terkait keterlibatan pemangku kepentingan hanya sebatas koordinasi dengan Satgas COVID-19 Kelurahan Siswodipuran melalui ketua RW yang nantinya di koordinasikan lagi dengan instansi pemerintah terkait seperti Puskesmas, Dinas Kesehatan, dan Dinas Sosial.

Operasional program Jogo Tonggo Dk.Gatak hanya bertumpu pada dana swadaya masyarakat tanpa adanya alokasi dana khusus. Pemberdayaan masyarakat di Dk.Gatak melalui program Jogo Tonggo dapat dikatakan sebagian berhasil, sebagian gagal. Keberhasilan pemberdayaan masyarakat terlihat pada keikutsertaan warga Dk.Gatak secara sukarela terlibat langsung selama pelaksanaan penanggulangan COVID-19 di lingkungan RW. Akan tetapi sebagian warga lain kesadaran terkait pentingnya penanggulangan COVID-19 masih rendah, hal ini dibuktikan dengan ketidak percayaan warga dengan COVID-19, tidak patuh dengan protokol kesehatan seperti penggunaan masker, menjaga jarak, menghindari kerumunan, dan penggunaan sarana CTPS (Cuci Tangan Pakai Sabun). Seharusnya warga di lingkungan RW wajib memberikan dukungan dan berperan aktif dalam kegiatan Jogo Tonggo, wajib menjalankan protokol kesehatan, dan wajib mentaati seluruh hasil keputusan dari rembugan Satgas Jogo Tonggo terkait penanggulangan COVID-19. ${ }^{6}$

Dalam upaya peningkatan kesadaran warga terkait penanggulangan COVID-19 melalui pemberdayaan masyarakat program Jogo Tonggo Dk.Gatak belum sepenuhnya berhasil. Tingkat pengetahuan warga masih berbeda-beda yang dapat menghambat dalam tumbuhnya kesadaran. Diperlukan pengoptimalan sosialiasi dan edukasi kepada warga yang dapat bekerjasama dengan tokoh masyarakat di masing-masing RT.

Pelaksanaan

pemberdayaan masyarakat di Dk.Gatak tidak didukung dengan pembentukan sanksi atau hukuman kepada warga yang melanggar aturan protokol kesehatan. Hal ini mengakibatkan pelanggar dapat dengan leluasa melakukan pelanggaran, sehingga menghambat tumbuhnya kesadaran masyarakat mengenai pentingnya penanggulangan COVID-19. Tidak adanya pelatihan kepada anggota Satgas mengakibatkan perbedaan pemahaman terkait kejelasan tujuan, tugas, dan wewenang pelaksana. Pihak-pihak terkait perlu memberikan pendampingan, monitoring dan evaluasi terhadap pelaksanaan progam Jogo Tonggo di Dk.Gatak RW 05, Siswodipuran.

\section{KESIMPULAN}

Program Jogo Tonggo Dk.Gatak RW 05 , Siswodipuran belum berjalan optimal. Hal ini dapat dilihat dari bidang kesehatan yang baru berhasil melaksanakan 4 dari 8 kegiatan, bidang ekonomi hanya 3 dari 9 kegiatan, dan bidang sosial keamanan melaksanakan sebanyak 5 dari 12 kegiatan. Sedangkan untuk bidang hiburan telah berhasil dilakukan, walaupun belum terlaksana secara rutin.

Faktor yang mempengaruhi kurang optimalnya pelaksanaan Jogo Tonggo Dk.Gatak yaitu pelaksana kurang memahami tujuan dari program, presepsi pelaksana yang berbeda mengenai pelaksanaan program, pelaporan tidak berjalan secara rutin dan tertulis, tidak terdapat pelatihan peningkatan kapasitas SDM anggota Satgas, tidak terdapat anggaran khusus, fasilitas dan sarana prasarana masih terbatas, belum semua anggota Satgas berperan aktif selama pelaksanaan program, terdapat ketergantungan yang tinggi pada pemerintah desa dan ketua RW, SOP Jogo Tonggo tingkat RT/RW belum terbentuk, serta 


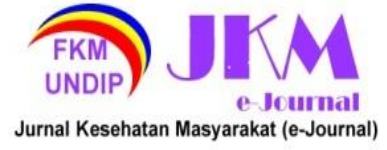

sosialisasi kepada anggota Satgas maupun masyarakat masih sangat minim.

\section{SARAN}

Saran yang diberikan kepada Satgas Jogo Tonggo Dk.Gatak agar meningkatkan edukasi kepada masyarakat, membentuk SOP Jogo Tonggo tingkat RT/RW, melaksanakan kegiatan Jogo Tonggo sesuai dengan pembagian tugas masing-masing bidang, melaksanakan pelaporan secara rutin dan tertulis, serta mengadakan rembug Jogo Tonggo secara rutin dan intensif. Saran bagi Satgas COVID-19 Kelurahan Siswodipuran agar dapat memberikan sosialiasi penanggulangan COVID19 kepada Satgas Jogo Tonggo dan masyarakat, merencanakan alokasi anggaran dari dana desa untuk anggaran khusus Jogo Tonggo, dan melakukan pelaporan secara rutin. Saran kepada Puskesmas Boyolali 1 agar dapat mengaktifkan kembali ambulance keliling dalam memberikan edukasi kepada masyarakat, serta memberikan masukan kepada Satgas jika ditemukan masalah kesehatan. Saran bagi Pemerintah Kabupaten Boyolali agar dapat memberikan pelatihan kepada anggota Satgas Jogo Tonggo, melakukan monitoring dan evaluasi secara berkala serta menjamin pemenuhan fasilitas pendukung dan bantuan sosial kepada warga yang terdampak maupun terpapar COVID-19.

\section{DAFTAR PUSTAKA}

1. Keputusan Menteri Kesehatan Republik Indonesia. Keputusan Menteri Kesehatan Republik Indonesia Nomor HK.01.07/MenKes/413/2020 Tentang Pedoman Pencegahan dan Pengendalian Corona Virus Disease 2019 (Covid-19). MenKes/413/2020. 2020;2019.

2. Satuan Tugas Penanganan COVID-19. Peta Sebaran COVID-19 [Internet]. 2020. Available from: https://covid19.go.id/

3. Pemerintah Provinsi Jawa Tengah. Sebaran Kasus COVID-19 di Jawa Tengah [Internet]. 2020. Available from: https://corona.jatengprov.go.id/

4. Pemerintah Kabupaten Boyolali. Monitoring Data Kabupaten Boyolali [Internet]. 2020. Available from: https://covid19.go.id/petasebaran-covid19

5. Arditama E, Puji L. Jogo Tonggo: Membangkitkan Kesadaran dan Ketaatan Warga Berbasis Kearifan Lokal pada Masa
Pandemi COVID-19 di Jawa Tengah. J Pendidik Kewarganegaraan Undiksha [Internet]. 2020;8(2):2599-686. Available from:

https://ejournal.undiksha.ac.id/index.php/JJP $P$

6. Dinas Kesehatan Provinsi Jawa Tengah. Petunjuk Teknis Satgas Jogo Tonggo Bidang Kesehatan Percepatan Penanganan COVID19 Berbasis Masyarakat Tingkat RW Di Jawa Tengah. In Semarang; 2020.

7. AL L, Hariwibowo. Penggunaan Desinfektan dan Antiseptik pada Pencegahan Penularan Covid-19 di Masyarakat. Maj Farmasetika. 2020;5:137-45.

8. Biomi AA, Artini MR, Made N, Tresnayani N, Kesehatan FI, Internasional UB, et al. HUBUNGAN TINGKAT PENGETAHUAN ALAT PELINDUNG DIRI ( APD ) DENGAN KEPATUHAN PEMAKAIAN ALAT PELINDUNG DIRI ( APD ) PADA PETUGAS PENYEMPROTAN DESINFEKTAN DI DENPASAR. J Policy Manag Rev. 2020;4(1):1-5.

9. Karo MB. Perilaku Hidup Bersih dan Sehat ( PHBS ) Strategi Pencegahan Penyebaran Virus Covid-19. 2012;1-4.

10.Pramudita $M$, Anggraini DD, Hidayat $N$, Yuniardiningsih E, Apriliyanti MD, Wangi P. Lumbung Pangan Sebagai Upaya Ketangguhan Pangan Masa Pandemi Covid19 Desa Kabuaran Bondowoso. Multidiciplinary J. 2020;3:34-40.

11.Eddy SA, DKK. Dampak COVID-19 terhadap Perekonomian Masyarakat dan Pembangunan Desa. J Chem Inf Model [Internet]. 2020;21(1):1-9. Available from: https://doi.org/10.1016/j.tmaid.2020.101607 \%OAhttps://doi.org/10.1016/j.ijsu.2020.02.03 4\%0Ahttps://onlinelibrary.wiley.com/doi/abs/1 0.1111/cjag. $12228 \% 0$ Ahttps://doi.org/10.101 6/j.ssci.2020.104773\%0Ahttps://doi.org/10.10 16/j.jinf.2020.04.011\%0Ahttps://doi.o

12.Badan Pusat Statistik Kabupaten Boyolali. Kecamatan Boyolali Dalam Angka Selo Subdistrict in Figures 2020. Boyolali: BPS Kabupaten Boyolali; 2020. 1-82 p.

13.Siagian TH. MENCARI KELOMPOK BERISIKO TINGGI TERINFEKSI VIRUS CORONA DENGAN DISCOURSE NETWORK ANALYSIS. J Kebijak Kesehat Indones. 2020;09(02):98-106.

14. Pemerintah Provinsi Jawa Tengah. Instruksi Gubernur Jawa Tengah Nomor 1 Tahun 


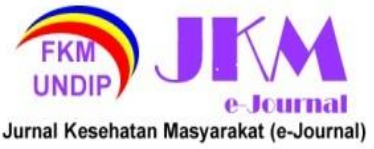

2020. Semarang; 2020.

15.Erwan Agus Purwanto P., Dyath Ratih Sulistiyastuti MS, Kasmad Rulinawaty SSMS. STUDI IMPLEMENTASI KEBIJAKAN PUBLIK [Internet]. 2018. 194 p. Available from: www.gavamedia.net

16. Shofi R. Analisis Implementasi Program Jogo Tonggo di Dusun Pelem Desa Sendangsari Kabupaten Rembang. 2020.

17.Imaroh RK. Analisis Implementasi Pelayanan Voluntary Counseling and Testing (VCT) di Puskesmas Kota Salatiga. 2017;

18. Prakusya L. Analisis Implementasi Program
Desa Tanggap COVID-19 di Desa Meteseh. 2020.

19.Suryaningrum FN. HUBUNGAN PENGETAHUAN DAN PERSEPSI MASYARAKAT DENGAN UAPAYA PENCEGAHAN COVID-19 DI KELURAHAN SRONDOL WETAN, SEMARANG. 2020.

20. Pemerintah Provinsi Jawa Tengah. Pedoman Percepatan Penanganan COVID-19 Berbasis Masyarakat melalui Pembentukkan Satgas Jogo Tonggo. 2020. 1-14 p. 